\title{
A performance comparison of transformer-less grid tied PV system using diode clamped and neutral point shorted inverters
}

Suroso, Hari Siswantoro

Department of Electrical Engineering, Jenderal Soedirman University, Indonesia

\begin{tabular}{|c|c|}
\hline Article Info & ABSTRACT \\
\hline & \multirow{8}{*}{$\begin{array}{l}\text { Grid tied photovoltaic (PV) system is an operation mode of PV system } \\
\text { working together with utility power supply to provide power to the power } \\
\text { load. Conventionally, transformer is used together with the power inverter. } \\
\text { The power transformer works as galvanic insolation amongst PV system and } \\
\text { power grid. It works also to raise the voltage of power inverter. However, use } \\
\text { of transformer will add system complexity, price, weight and size of the } \\
\text { entire system. Transformer-less system is an alternative to make the system } \\
\text { simpler and more practical in use. The paper discusses performance of } \\
\text { transformer-less grid tied PV systems using diode clamped and neutral point } \\
\text { shorted inverters. Effects of transformer elimination to the feat of the grid } \\
\text { tied PV system especially harmonics content and leakage current of PV } \\
\text { system were examined and analyzed. The performance was also compared } \\
\text { with the traditional system using H-bridge inverter. The leakage currents did } \\
\text { not flow in the system applying diode clamped inverter, and neutral point } \\
\text { shorted inverter. In case of harmonics content, the diode clamped inverter } \\
\text { injected less harmonics components than the neutral point shorted inverter. } \\
\text { The neutral point shorted provides a simpler inverter circuit in the } \\
\text { transformerless systems. }\end{array}$} \\
\hline Received Jul 17, 2019 & \\
\hline Revised Nov 22, 2019 & \\
\hline Accepted Feb 1, 2020 & \\
\hline Keywords: & \\
\hline Grid tied photovoltaic & \\
\hline H-bridge inverter & \\
\hline Transformer-less system & \\
\hline
\end{tabular}

This is an open access article under the CC BY-SA license.

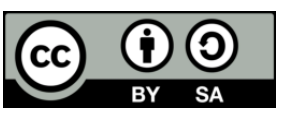

\section{Corresponding Author:}

Suroso,

Department of Electrical Engineering,

Jenderal Soedirman University,

J1. Mayjen Sungkono km. 5, Blater, Purbalingga, Jawa Tengah 53371, Indonesia.

Email: suroso.te@unsoed.ac.id

\section{INTRODUCTION}

Photovoltaic (PV) cells are applied to capture and proceed the light energy of the sun into electrical energy. To generate higher output power, some solar cells are constructed to form a PV module. These PV modules are linked and constructed in series and parallel to acquire larger output voltage or current [1-3]. The generated power of PV systems is in the form of dc voltage or dc current. To supply ac power load, a power inverter is needed. The inverter proceeds the dc power of PV system to be ac power with controllable magnitude, frequency and phase angle of its current and voltage [4-8].

In general, two operation types of photovoltaic system were introduced and used. The first type is stand-alone operation. In this stand-alone operation, the photovoltaic supplies electrical energy to the power load [9-10]. Power converters are needed to make the output power suitable for the loads, i.e. dc or ac loads. In the second operation type, the PV system is connected to the ac power grid, working together to comply power to the ac power load. In this case, the power inverter is utilized as interface among the PV system and ac power grid [11-13]. Hence, it changes the dc voltage of photovoltaic system into ac voltage. Power inverter also regulates the power that will be sent into the power grid. In the second operation type, the power 
transformer is conventionally employed to raise the output voltage of PV system. It works also as galvanic insulation between PV system and ac power grid [14-16]. Nevertheless, application of low frequency power transformer will add the weight, volume, cost and power losses of system [17-19]. Moreover, the existence of dc current component in the system will cause core saturation of power transformer. It may result in overheating and fault of transformer. In some topologies, high frequency power transformer is applied to minimize the size and volume of the entire system. However, efficiency is still a problem in this system. Power losses in a high frequency power transformer is still a remained problem [20-22].

An alternative method to integrate the PV system with power grid is by eliminating the power transformer. This technique is called as transformer-less photovoltaic system. In this transformer-less method, the PV is linked to the power grid without using power transformer [23-29]. As a result, the system become much simpler. It also eliminates the power losses generated by the transformer. However, leakage current is another new problem introduced in this system [30-34]. Eliminating leakage current in this type system will be greatly give advantage. This paper discusses a different transformer-less grid connected photovoltaic system using three-level neutral-point-shorted (TLNPS) inverter circuits. The performance was compared with transformerless system using three-level diode-clamped (TLDC) inverter [6, 26, 28, 29]. The TLDC inverter consists of four power switches and two power diodes. In case of the TLNPS inverter circuit, it is constructed with four power switches only. They operate in pulse width modulation (PWM) operation. The power delivered into the grid is regulated by proportional integral current control. The performances were evaluated by using computer simulation tests. The features of the system were also compared to the system employing conventional H-bridge inverter.

\section{PROPOSED GRID TIED PV SYSTEM}

Figure 1 presents a conventional of grid tied photovoltaic system using H-bridge voltage source inverter and power transformer. The H-bridge inverter works to produce ac output voltage from dc input voltage generated by the photovoltaic system. The transformer in this system is employed to level-up the ac voltage of inverter to meet the power grid voltage. Hereafter, Figure 2 shows configuration of a grid tied photovoltaic system without transformer called as transformer-less system. Power transformer is eliminated in this system. To obtain a higher ac output voltage, two alternative ways can be applied. The first one is by connecting some photovoltaic modules in series. Hence, the dc input voltage will be higher. The second manner is by utilizing dc-dc step-up power converter. The low dc voltage of photovoltaic is boosted to meet the ac grid voltage. Another feature such as maximum power point tracking (MPPT) system can be realized in the dc-dc converter to obtain maximum energy of sunlight.

In fact, there are parasitic capacitances between the PV systems and ground. These parasitic capacitance values are not fixed. They are greatly affected by environmental conditions, and PV module construction. Typically, the parasitic capacitance values range from $50-150 \mathrm{nF} / \mathrm{kW}$ [35]. The parasitic capacitances could add losses, and cause risk for human as PV operator. These parasitic capacitances are represented by capacitance $\mathrm{C}_{\mathrm{pv} 1}$ and $\mathrm{C}_{\mathrm{pv} 2}$ as shown in Figure 2. In this paper, three systems are considered and tested. The first system is by using conventional H-bridge inverter as indicated in Figure 3. The H-bridge inverter is constructed by four controlled power switches. The second system is by applying the TLDC inverter as shown in Figure 4. Four controlled switches plus two power diodes are required to build this inverter circuit. The third system is a new system. This system utilizes TLNPS inverter as depicted in Figure 5. Four controlled switches are used to construct this inverter. The TLNPS inverter circuit is simpler than the TLDC inverter, because of it needs only four power switches without power diodes. The inverter circuits are linked to the ac power grid directly without power transformer.

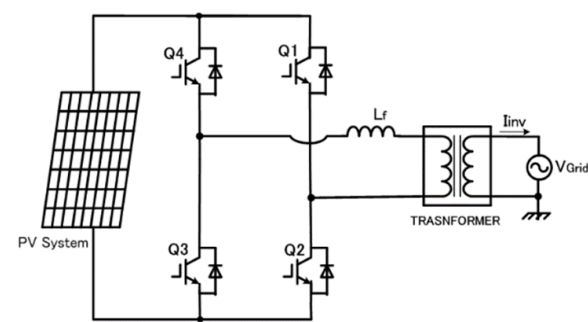

Figure 1. Conventional grid tied PV system $[4,5]$

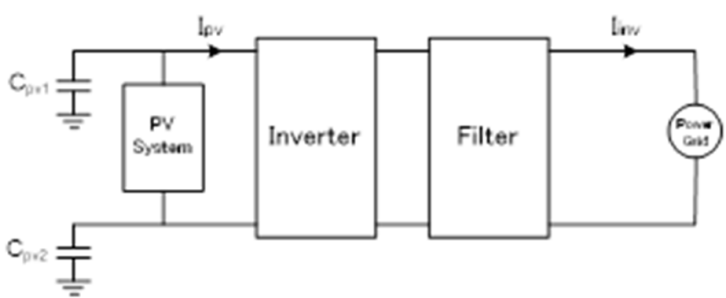

Figure 2. Transformer-less PV system 

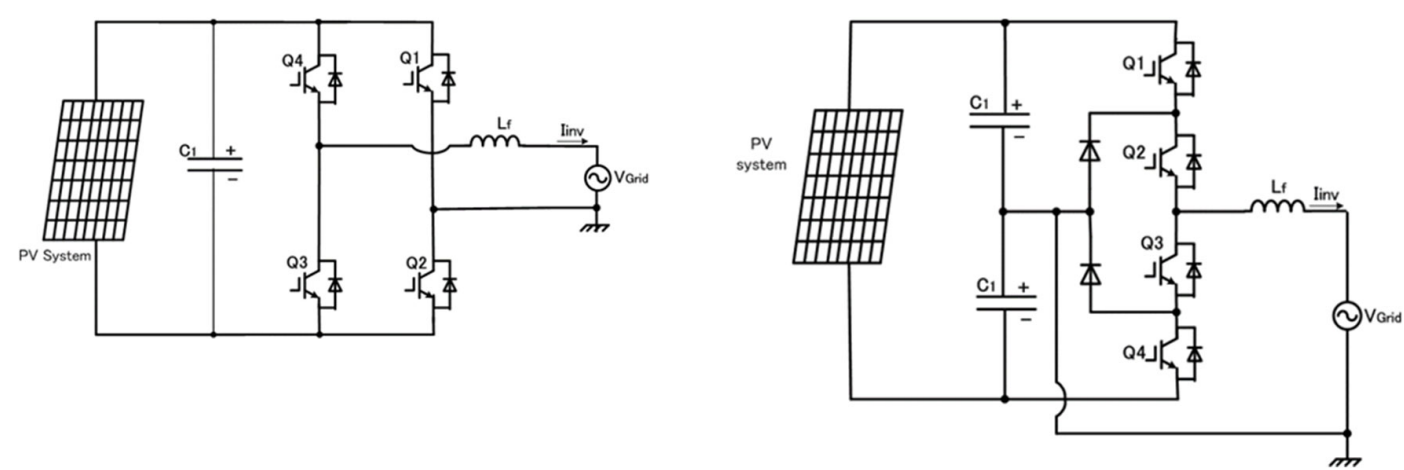

Figure 3. Transformer-less PV systems using Hbridge inverter [25]

Figure 4. Transformer-less PV systems using TLDC inverter

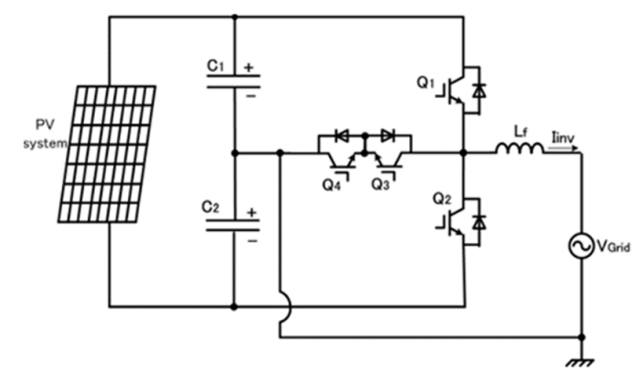

Figure 5. Proposed transformer-less PV using TLNPS inverter

To manage the power sent to the power grid, a proportional integral (P-I) current controller was employed together with the pulse width modulation circuits. Figure 6 shows the controller applied in the inverter system. This controller is the same for all three inverter systems. The PWM strategy implemented carrier and sinusoidal signals to generate firing signal of inverter's power switches. The signals $\mathrm{C}_{\mathrm{r} 1}$ and $\mathrm{C}_{\mathrm{r} 2}$ are the carrier signals to generate pulse width modulation (PWM) wave. The outputs of the comparators will be the inputs of gate drive circuits of power switches.

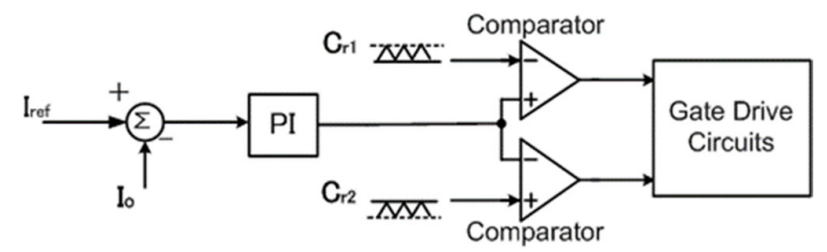

Figure 6. Current controller of inverter system

\section{TEST RESULTS AND DISCUSSION}

The performance of the proposed transformer-less grid connected PV system making use of TLNPS inverter was tested and evaluated by computer simulations of power PSIM software. Thereunto, the performance of the new system was compared with two other systems, i.e. H-bridge and TLDC inverter systems. The conditions and parameters were set the same for all inverter-PV systems. The difference was only the inverter circuits applied as power converter.

\subsection{Transformer-less System with H-bridge inverter}

The transformer-less H-bridge system as indicated in Figure 3 was tested. Table 1 lists the parameters in this test. The PV system was epitomized by dc voltage source with magnitude $220 \mathrm{~V}$.

Int J Pow Elec \& Dri Syst, Vol. 11, No. 2, June 2020 : $702-710$ 
The inverter circuit was operated in $22 \mathrm{kHz}$ switching frequency. Parasitic capacitance values of PV system were set as $100 \mathrm{nF}$, and $1 \mathrm{nF}$ while the filter inductor was $1 \mathrm{mH}$. The inverter system was linked to $220 \mathrm{~V} 50$ $\mathrm{Hz}$ ac power grid. Figure 7 presents the waveforms of inverter's current sent into the power grid by H-bridge inverter circuit, and power grid voltage waveform. In this test, the magnitude of the ac current was set as 15 A. Figure 8 presents the harmonics content of the injected current. The odd harmonics orders were the predominant, i.e. $3^{\text {rd }}, 5^{\text {th }}, 7^{\text {th }}$ with magnitudes $0.31 \%, 0.25 \%$ and $0.18 \%$, respectively. Figure 9 and Figure 10 depict the leakage currents $\mathrm{IC}_{\mathrm{pv} 1}$ and $\mathrm{IC}_{\mathrm{pv} 2}$ flowing thru the parasitic capacitances. As one see in these figures, a larger parasitic capacitance value will cause larger leakage currents in the PV system.

Table 1. Test parameter of system.

\begin{tabular}{ll}
\hline \multicolumn{1}{c}{ Parameters } & Value \\
\hline DC voltage source & $220 \mathrm{~V}$ \\
Power grid, rms & $220 \mathrm{~V}$ \\
Switching frequency & $22 \mathrm{kHz}$ \\
Filter inductor & $1 \mathrm{mH}$ \\
Parasitic capacitance of PV & $100 \mathrm{nF}, 1 \mathrm{nF}$ \\
Load & $\mathrm{R}=20 \Omega, \mathrm{L}=5 \mathrm{mH}$ \\
\hline
\end{tabular}

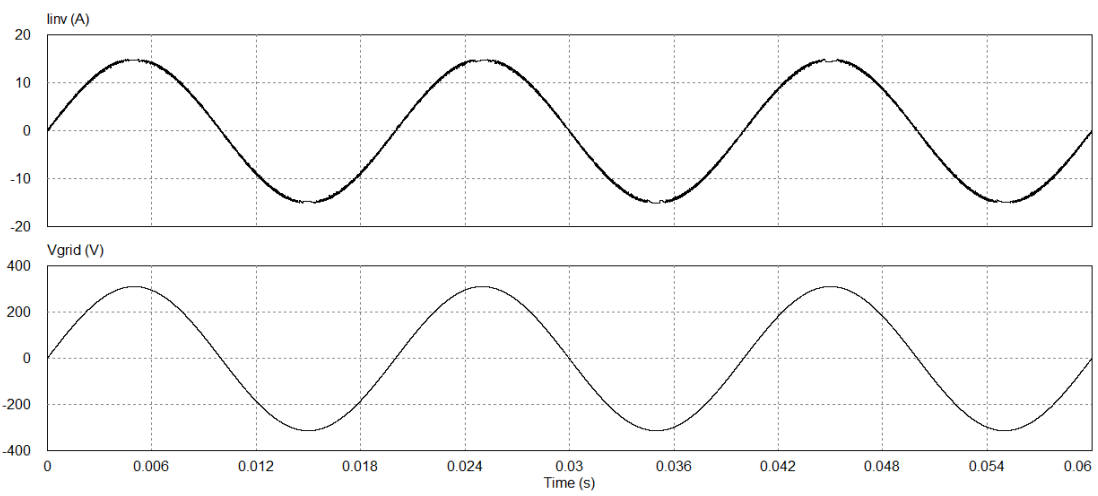

Figure 7. H-bridge inverter injected current $\left(\mathrm{I}_{\text {inv }}\right)$, and grid voltage $\left(\mathrm{V}_{\text {grid }}\right)$

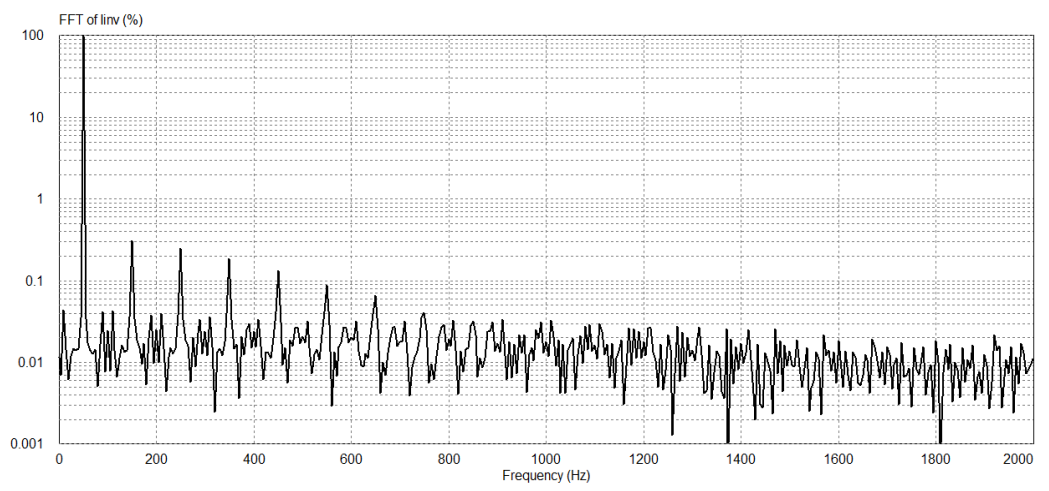

Figure 8. Harmonics spectra of current, $\mathrm{I}_{\mathrm{inv}}$ 


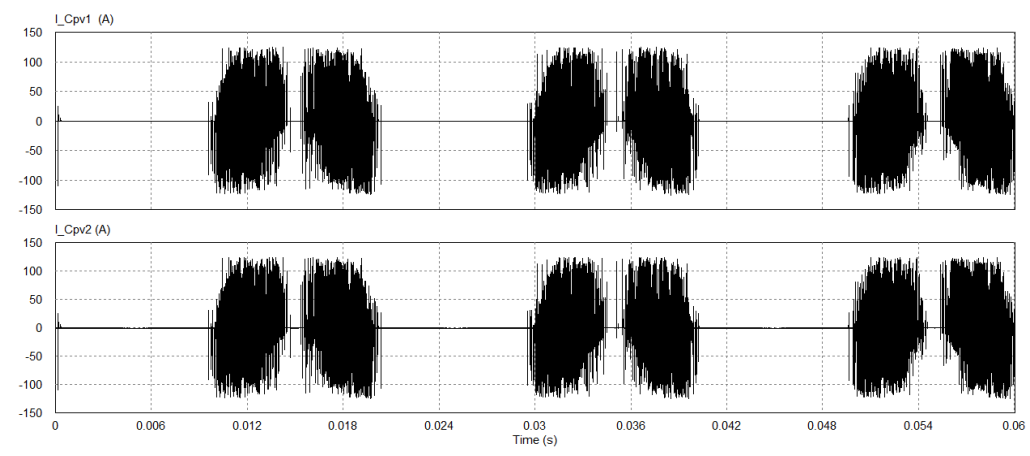

Figure 9. Leakage currents at $\mathrm{C}_{\mathrm{pv}}=100 \mathrm{nF}$

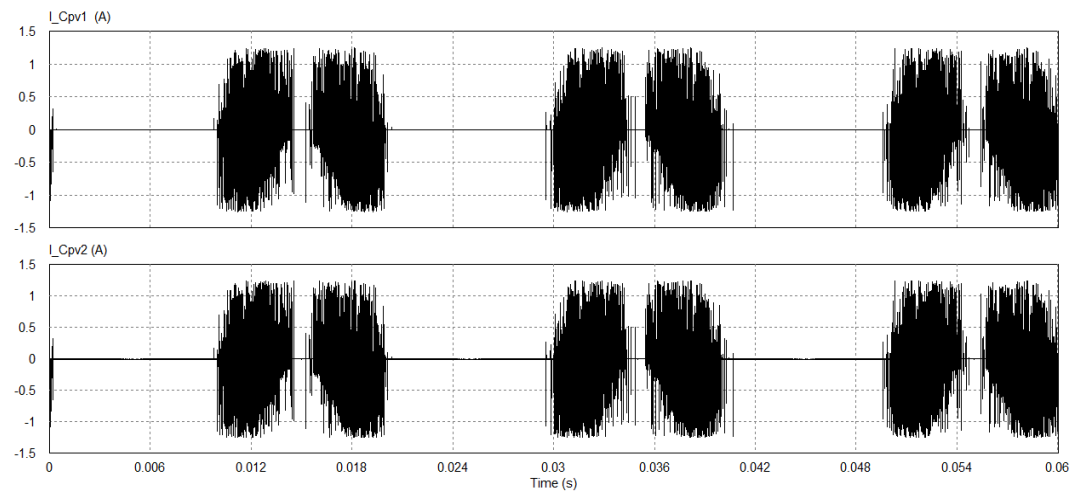

Figure 10. Leakage current in H-bridge based grid connected PV system at $\mathrm{C}_{\mathrm{pv}} 1 \mathrm{nF}$

\subsection{Transformer-less system using TLDC inverter}

The PV-inverter system employing TLDC inverter as described in Figure 4 was tested with the same parameters as in Table 1. Figure 11 presents the wave forms of inverter's ac current and power grid voltage. A sinusoidal ac current was sent to power grid by using the TLDC inverter system. The low frequency harmonics orders of inverter's current is shown in Figure 12. As one can see in the figure, magnitudes of the $3^{\text {rd }}, 5^{\text {th }}$, and $7^{\text {th }}$ harmonics components were getting down compared with the harmonics of inverter's current produced in H-bridge inverter circuit. Magnitudes of the $3^{\text {rd }}, 5^{\text {th }}$, and $7^{\text {th }}$ harmonics components in this figure are $0.032 \%, 0.04 \%$ and $0.061 \%$, successively. Figure 13 presents the captured zero leakage current waveforms in this system. Using the diode clamped inverter, the leakage currents have been eliminated.

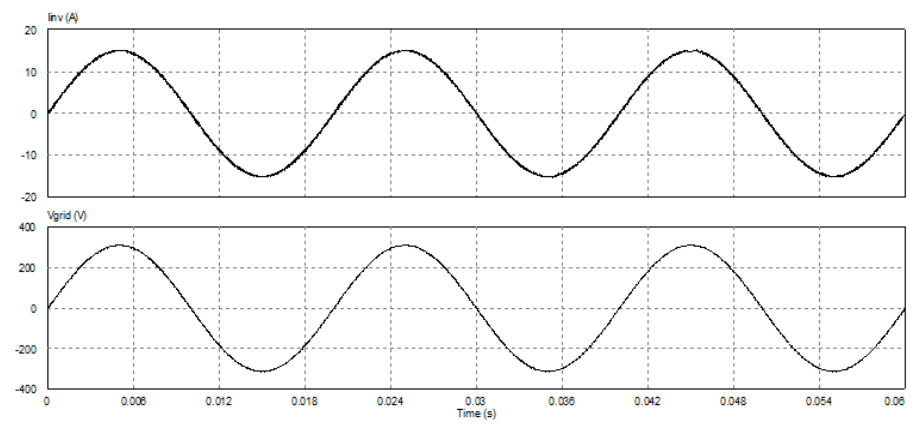

Figure 11. Inverter's current and power grid voltage 


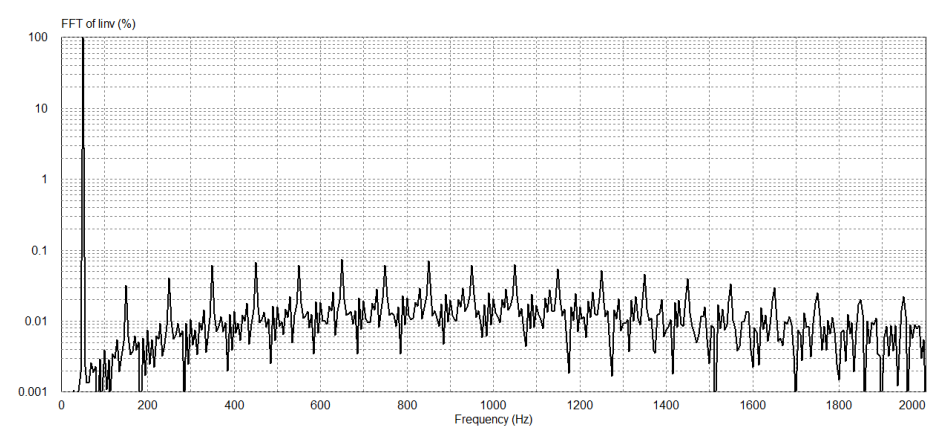

Figure 12. Harmonics spectra of inverter's current

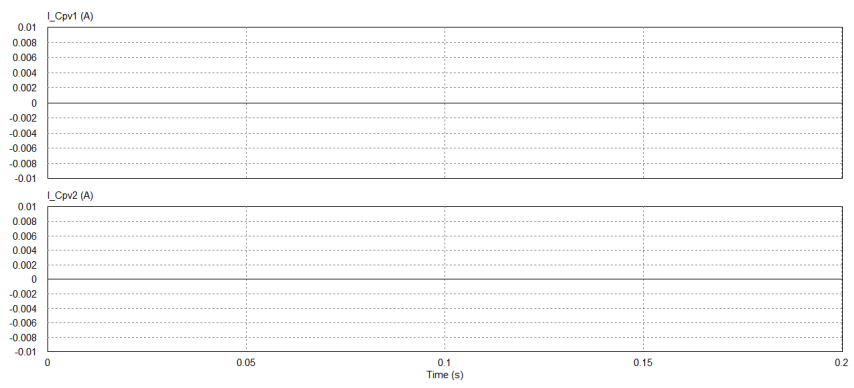

Figure 13. Leakage currents of TLDC inverter system

\subsection{Proposed transformer-less system using TLNPS inverter}

The third system is the PV system applying the three-level neutral point shorted (TLNPS) inverter circuit as the power conditioner and interface shown in Figure 5. By using this inverter circuit, a three-level voltage waveform also can be obtained. The TLNPS inverter circuit needs four power switches, only. It is simpler than the TLDC inverter. Its output waveform is the same with the waveform of H-bridge and TLDC inverters, i.e. three-level voltage wave form. The PV-inverter system using TLNPS inverter was examined as the systems employed H-bridge and TLDC inverters. Figure 14 are the waveforms of the delivered current and grid voltage in this system. A sinusoidal current was injected to the ac power grid by using TLNPS inverter. The harmonic spectra of the injected ac current is shown in Figure 15. The magnitudes of the low harmonic orders especially the $3^{\text {rd }}, 5^{\text {th }}$ and $7^{\text {th }}$ were $0.28 \%, 0.22 \%$ and $0.18 \%$ respectively. The leakage currents in this system did not appear as shown in Figure 16. Hence, this TLNPS system was also able to remove the leak currents in the PV system. Figure 17 shows a comparison of low harmonics components of output current sent to the ac power grid by H-bridge, TLDC and TLNPS inverters. As can be noticed in this figure, the TLDC inverter delivered the lowest magnitude of harmonics components. Its total harmonics distortion is also the smallest among the three-systems.

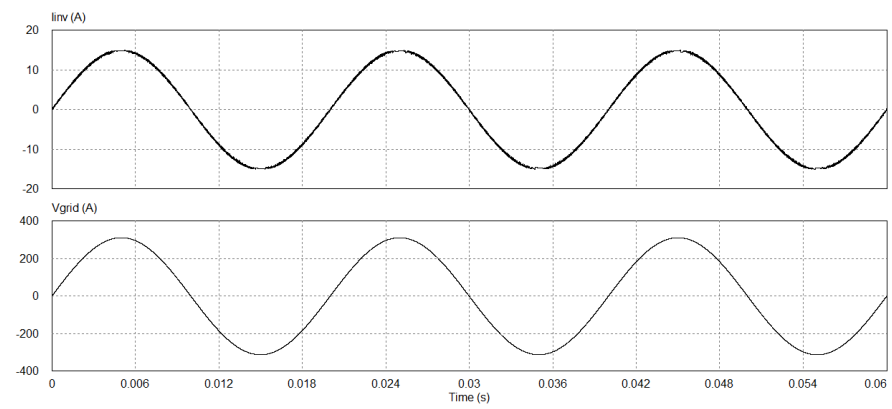

Figure 14. Delivered current by inverter and ac grid voltage 


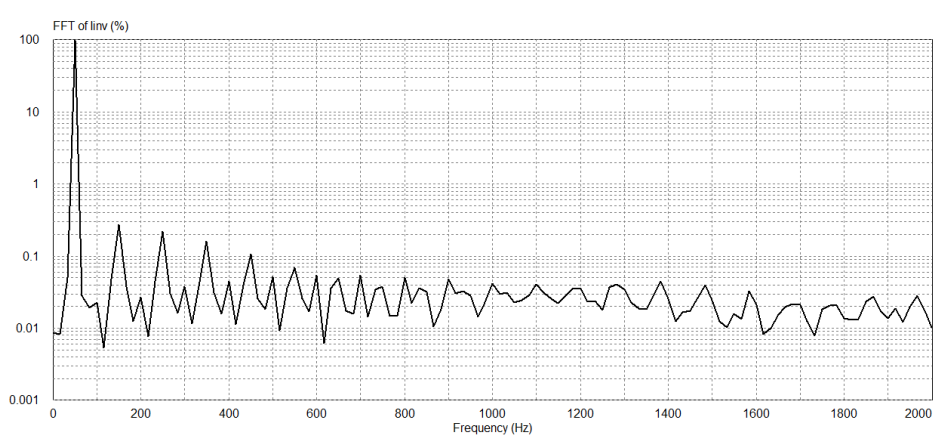

Figure 15. Harmonics components of TLNPS inverter current
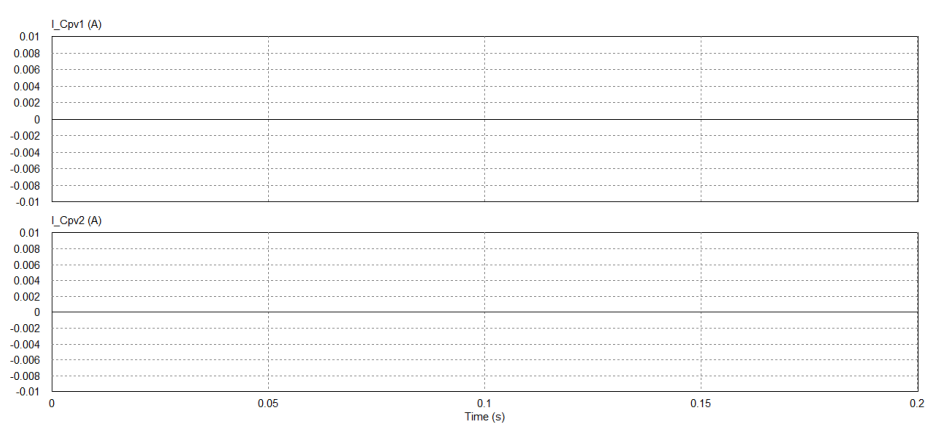

Figure 16. Leakage current waveforms of TLNPS inverter system

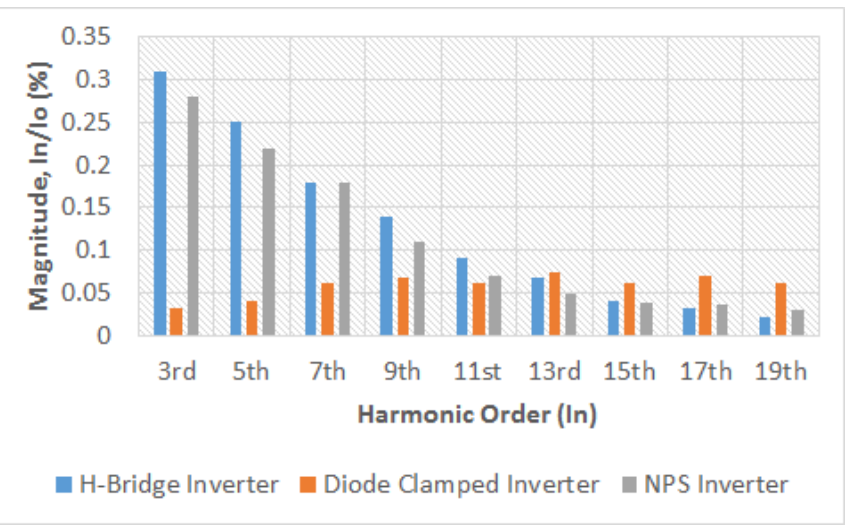

Figure 17. Comparison of injected current harmonic orders

\section{CONCLUSION}

This paper presented performances of transformer-less grid tied PV systems using H-bridge, TLDC and TLNPS inverter circuits. The H-bridge inverter generates non-zero leak current during transformer-less grid tied operation of PV system. The larger the parasitical capacitances of PV system will rise the magnitude of leakage current. The suggested transformer-less grid tied PV system using TLNPS inverter worked well with zero leak current. The TLNPS inverter has merit related with its simpler circuit than TLDC inverter. Ac current distortion of the transformer-less grid tied PV system using TLDC inverter is smaller than the TLNPS and H-bridge inverters.

Int J Pow Elec \& Dri Syst, Vol. 11, No. 2, June 2020 : $702-710$ 


\section{REFERENCES}

[1] G. N. Tiwari, R.K. Mishra, and S.C. Solanki, "Photovoltaic modules and their applications: A review on thermal modelling", Applied Energy, vol 88, pp.2287-2304, 2011.

[2] A. S. Joshi, I. Dincer, and B. V. Reddy, "Performance analysis of photovoltaic systems: a review", Renewable and Sustainable Energy Reviews, vol 13, pp. 1884-1897, 2009.

[3] D. Hwang, J. Lee, and Y. Cho, "Single-phase single-stage dual-buck photovoltaic inverter with active power decoupling strategy", Renewable Energy, vol 126, pp. 454-464, 2018.

[4] S. B. Kjaer, J. K. Pedersen, and F. Blaabjerg, "A review of single-phase grid-connected inverters for photovoltaic modules", IEEE Transactions Industrial Application, vol 41, no. 5, pp. 1292-1306, 2005.

[5] J. M. Carrasco, L.G. Franquelo, Bialasiewicz, J.T., and Alfonso, N.M, "Power-electronics systems for the grid integration of renewable energy sources: a survey", IEEE Transactions on Industrial Electronics, vol 53, pp. 1002 $1016,2008$.

[6] J. Rodriguez, S. Bernet, P. K. Steimer, and I. E. Lizama, "A survey on neutral-point-clamped inverters", IEEE Transactions on Industrial Electronics, vol 57, no. 7, pp. 2219-2230, 2010.

[7] X. Zhang, H. Ni, D. Yao, R.x. Cao, and W.X. Shen, "Design of single-phase grid-connected photovoltaic power plant based on string inverters", $1^{\text {st }}$ IEEE Conference on Industrial Electronics and Applications, pp. 1-5, 2006.

[8] Suroso, D. T. Nugroho, and T. Noguchi, "A nine-level hybrid current source inverter using common-emitter topology and inductor-cell", International Journal of Power Electronics and Drive Systems (IJPEDS), vol 10, no. 2, pp. 852-859, 2019.

[9] N. C. Nair, and N. Garimella, "Battery energy storage systems: assessment for small-scale renewable energy integration", Energy and Buildings, vol 42, pp. 2124-2130, 2010.

[10] H. Liu, and S. Wu, "An assessment on the planning and construction of an island renewable energy system e A case study of Kinmen Island”, Renewable Energy, vol 35, pp. 2723-2732, 2010.

[11] S. Park, G. Cha, Y. Jung, and C. Won, "Design and application for PV generation system using a soft-switching boost converter with SARC", IEEE Transactions on Industrial Electronics, vol 57, no. 2, pp. 515-522, 2010.

[12] L. Lai, W. Hou, Y. Feng, and Y. Chen, "Novel grid-connected photovoltaic generation system", Third International Conference on Electric Utility Deregulation and Restructuring and Power Technologies, pp. 2536-2541, 2008.

[13] V. J. Farias, and L. C. G. de Freitas, "Dual transformerless single-stage current source inverter with energy management control strategy", IEEE Transactions on Power Electronics, vol 28, no. 10, pp. 4644-4656, 2012.

[14] P. G. Barbosa, H. A. C. Braga, M. C. Barbosa, and E. C. Teixeria, "Boost current multilevel inverter and its application on single phase grid connected photovoltaic system", IEEE Transactions on Power Electronics, vol 21, pp. 1116-1124, 2006.

[15] C. Wu, "Topology for current-source grid-connected inverter with improved efficiency and pulse width modulation control strategy", Journal of Shanghai University, vol 12, pp. 554-559, 2008.

[16] Suroso, D. T. Nugroho, Amran, and T. Noguchi, "Parallel operation of current-source inverter for low-voltage high-current grid-connected photovoltaic system", International Journal of Electrical and Computer Engineering, vol 9, no. 4, pp. 2220-2229, 2019.

[17] R. Gonzlez, E. Guba, J. Lpez, and L. Marroyo, "Transformerless single-phase multilevel-based photovoltaic inverter", IEEE Transactions on Industrial Electronics, vol 55, no. 7, pp. 2694-2702, 2008.

[18] Jayalakshmi N. S., Ankit K., and Ashish K., "Analysis and design of single-phase high efficiency transformer less PV inverter topology", International Journal of Power Electronics and Drive System, vol 9, no. 2, pp. 730-737, 2018.

[19] Dauta, M. Irwantoa, Y.M. Irwana, N. Gomesha, M. adzria, and M. Fitraa, "High power transformerless photovoltaic inverter", Energy Procedia, pp. 465 - 472, 2013.

[20] V. Gerardo, M. P. Raymundo, and S. J. Miguel, "High efficiency single-phase transformer-less inverter for photovoltaic applications", Ingeniería Investigación y Tecnología, vol 6, no. 2, pp. 173-184, 2015.

[21] E. Koutroulis, and F. Blaabjerg, "Design optimization of transformerless grid-connected PV inverters including reliability", IEEE Transactions Power Electronics, vol 28, no. 1, pp. 325-335, 2013.

[22] T. Kerekes, R. Teodorescu, P. Rodríguez, G. Vázquez, and E. Aldabas, "A new high-efficiency single-phase transformerless PV inverter topology”, IEEE Transactions on Industrial Electronics, vol 58, no. 1, pp. 184-191, 2011.

[23] T. Salmi, M. Bouzguenda, A. Gastli, and A. Masmoudi, "A novel transformerless inverter topology without zerocrossing distortion", International Journal of Renewable Research, vol 2, no. 1, pp. 140-146, 2012.

[24] S. Vasconcelos, Araujo, P. Zacharias, and R. Mallwitz, "Highly efficient single-phase transformerless inverter for grid-connected photovoltaic systems", IEEE Transactions on Industrial Electronics, vol 57, no. 9, pp. 3118-3128, 2010.

[25] H. F. Xiao, S. J. Xie, C. Yang, and R. H. Huang, "An optimized transformerless photovoltaic grid-connected inverter", IEEE Transactions on Industrial Electronics, vol 58, no. 5, pp. 1887-1895, 2011.

[26] L. Zhang, K. Sun, L. Feng, H. Wu, and Y. Xing, "A family of neutral point clamped full-bridge topologies for transformerless photovoltaic grid-tied inverters", IEEE Transactions on Power Electronics, vol 28, no. 2, pp. 730738, 2013.

[27] Y. Gu, W. Li, Y. Zhao, B. Yang, C. Li, and X. He, "Transformerless inverter with virtual DC bus concept for costeffective grid-connected PV power systems", IEEE Transactions on Power Electronics, vol 28, no. 2, pp. 793-805, 2013. 
[28] F. Faraji, S.M. Mousavi G., A. Hajirayatc, A. A. M. Birjandie, and K. Al-Haddadf, "Single-stage single-phase three-level neutral-point-clamped transformerless grid-connected photovoltaic inverters: Topology review", Renewable and Sustainable Energy Reviews, vol 80, pp. 197-214, 2017.

[29] Prem sai. T, Ambica sony.S, Sumathi.A, and Umasankar.S, "Transformerless full bridge neutral point clamped inverter topology for renewable energy sources", International Conference on Advances in Electrical Engineering (ICAEE), pp. 1-6, 2014.

[30] O. Lo'pez, F. D. Freijedo, A. G. Yepes, P. Fern'andez-Comesãna, J. Malvar, R. Teodorescu, and J. Doval-Gandoy, "Eliminating ground current in a transformerless photovoltaic application", IEEE Transactions on Enegy Conversion, vol 25, no. 1, pp. 140-147, 2010.

[31] J. Lee, and K. Lee, "New modulation techniques for a leakage current reduction and a neutral-point voltage balance in transformerless photovoltaic systems using a three-level inverter", IEEE Transactions on Power Electronics, vol 29, no. 4, pp. 1720-1732, 2014.

[32] B. Yang, W. Li, Y. Gu, W. Cui, and X. He, "Improved transformerless inverter with common-mode leakage current elimination for a photovoltaic grid-connected power system", IEEE Transactions on Power Electronics, vol 27, no. 2, pp. 752-762, 2013.

[33] M. C. Cavalcanti, A. M. Farias, K. C. Oliveira, F. A. S. Neves, and J. L. Afonso, "Eliminating leakage currents in neutral point clamped inverters for photovoltaic system", IEEE Transactions on Industrial Electronics, vol 59, no. 1, pp. 435-443, 2012.

[34] T. Selmi, and M. Rezgui, "A novel DC-AC inverter topology to eliminate leakage current", International Journal of Power Electronics and Drive Systems, vol 9, no. 4, pp. 1733-1744, 2018.

[35] T. Kerekes, R. Teodorescu, and M. Liserre, "Common mode voltage in case of transformerless PV inverters connected to the grid," IEEE International Symposium on Industrial Electronics, pp. 2390-2395, 2008.

Int J Pow Elec \& Dri Syst, Vol. 11, No. 2, June 2020 : 702 - 710 